\title{
A Framework for an ICT-based Development Program for Science Teachers in State Universities and Colleges in Region VI
}

\author{
Amel L. Magallanes \\ Capiz State University, Philippines \\ Centro Escolar University, Philippines \\ St. Dominic College of Asia, Philippines \\ *Corresponding Author: amelmagallanes@gmail.com
}

Copyright (C) 2014 Horizon Research Publishing All rights reserved.

\begin{abstract}
Curriculum reform is central to the aspirations of many developing countries as they strive to deliver a quality education to their citizens. In State Universities and Colleges in Region VI, with its remarkable achievement of a high literacy rate in a few decades, the next step is bringing its resources to bear on providing a quality education so that Filipino science professors and students may take their places in the global labor force. This study concerns the integration of information and communications technologies (ICT) into the science curriculum of Higher Education Institutions in State Universities and Colleges in the Philippines particularly in Region VI, and the training and development requirements of science professors in this regard. A mixed methodology was employed to obtain qualitative data from 11 policy makers as represented by the Vice President of Academic Affairs of the SUC's in region $\mathrm{VI}$, and quantitative data from a questionnaire for which 139 replies were received from SUC's science professors in Region VI.The findings of this study confirmed those citations in the literature that inefficient management planning and inadequate resources influence the integration of ICT in the science curriculum. Furthermore, the qualitative and quantitative findings confirmed that teachers' access to training is affected by time constraints, ineffective ICT course material, unavailability of ICT infrastructures and facilities, and high cost of ICT trainings. The policy makers interviewed in this study perceived the teachers as having a positive attitude toward ICT integration in the science curriculum, quantitative data from the teachers pointed to a high interest in ICT integration, and their willingness to pursue further professional development in the effective use of ICT in the science curriculum. Furthermore, age factor exhibited a significant difference in ICT skills, utilization and individual barriers of science teachers in SUC's Region VI. The length of service also showed a very significant difference as to the ICT skills, utilization attitudes, and individual barriers of the teacher respondents. However, as to their gender and highest
\end{abstract}

educational attainment, home location and school location, there was no such factor implicating a non-significant difference in the attitudes, skills, utilization and perceived barriers.

Keywords Science Teachers, ICT-based Framework, Faculty Development

\section{Introduction}

Colleges and universities invest billions of dollars per year for the acquisition of instructional technology through ICT and other ICT tools.

Today, everyone needs a basic understanding of ICT and how to make productive use of it, just to be good teacher, students and citizens. Teaching people how to be competent basic users of ICT technologies is an important role of ICT education, so they will be successful in their academic and work careers, especially in teaching and learning and so they can efficiently participate in modern technical society.

Although ICT has several definitions depending on the nature of its use, for this study, ICT (information and communication technology) is used as an umbrella term that includes any communication device or application, encompassing: computer and network hardware and software, as well as the various services and applications associated with them, such as videoconferencing and distance learning. We refer to ICT in the particular context of ICT provision, policy and teacher factors that variously support teaching, learning and a range of activities in education.

Information Communication Technology (ICT) is increasingly becoming more widespread throughout university education worldwide. This is in line with UNESCO's policy paper for change and development in higher education which urges higher education institutions to 
make greater use of the advantages offered by the advancement of communication technology to improve the provision and quality of their education (Chitanana et al., 2008).

The widespread belief that ICTs can and will empower teachers and learners, transforming teaching and learning processes from being highly teacher-dominated to student-centered, and that this transformation will result in increased learning gains for students, creating and allowing for opportunities for learners to develop their creativity, problem-solving abilities, informational reasoning skills, communication skills, and other higher-order thinking skills.

However, the performance of ICT utilization in higher education is not expressly evident. Although most teachers may have considerable skills in ICT, they cannot integrate ICT into regular teaching effectively. This phenomenon has been the concern of the present researcher and has put forward worthy outcome and consideration to solve this problem. It is in this premise that this research study was conducted.

\section{Statement of the Study}

The main purpose of this research study was to develop a framework for an ICT-Based development program for Science teachers in State Universities and Colleges in Region VI. This study was performed with the guidance of the following research questions:

1. What was the extent of ICT skills, utilization, attitudes, and barriers of Science teachers of SUCs in Region VI regarding ICT?

2. What actions had been taken by the State Universities and Colleges (SUC's) in Region VI to integrate ICT into teaching and learning in science curriculum?

3. What programs had been introduced by the SUC's in Region VI to provide professional development for science professors to employ ICT in their classes?

4. What are the professional development needs of science teachers in Region VI regarding ICT use in science curriculum?

5. How did the science teachers' ICT skills, utilization, barriers, attitudes, and belief regarding ICT differ in terms of:

a. Age, Gender, Highest education attainment, Length of service, School location; and Home location?

6. What prototype professional framework is proposed based on the results of the research study?

\section{Results and Discussions}

\section{Respondents' Attitudes towards ICT in SUC's Region VI}

The data revealed that science teachers of SUC's Region VI strongly agreed that they were eager to learn more about using ICT for it has a positive impact on their teaching learning methodology. Furthermore, they also strongly agreed that ICT training is very beneficial for their personal and professional development and they are willing to use it if there is sufficient and relevant equipment available at their school. (See Table 1)

This implies that in spite that there was Science teachers in SUC's Region VI who felt confident about their ICT attitudes and usage in the classroom there were still a significant majority of Science teachers who do not see considerable learning benefits from using ICT, regardless of the sophistication of ICT systems. Therefore, Science teachers showed that their attitudes of ICT was more ambivalent unpredictable and sometimes doubtful' about current advantages of ICT in their teaching learning process. (See Table 1)

Table 1. Respondents Attitudes towards ICT

\begin{tabular}{|l|c|c|c|}
\hline & $\mathrm{X}$ & S.D. & V.I \\
\hline $\begin{array}{l}\text { I am eager to learn more about using ICT } \\
\text { for it has a positive impact on my } \\
\text { teaching learning methodology. }\end{array}$ & 4.741 & 0.472 & S.A \\
\hline $\begin{array}{l}\text { ICT training is very beneficial for my } \\
\text { personal and professional development. }\end{array}$ & 4.748 & 0.468 & S.A \\
\hline $\begin{array}{l}\text { Using ICT technology decreases student } \\
\text { teacher interaction. }\end{array}$ & 2.482 & 1.144 & D.A \\
\hline $\begin{array}{l}\text { The use of ICT is not necessary for } \\
\text { science lesson and laboratory activities. }\end{array}$ & 1.82 & 1.118 & D.A \\
\hline $\begin{array}{l}\text { I am willing to use ICT if there is } \\
\text { sufficient and relevant equipment } \\
\text { available at the school. }\end{array}$ & 4.576 & 0.742 & S.A \\
\hline $\begin{array}{l}\text { I prefer to use traditional method rather } \\
\text { than the using ICT equipment such as } \\
\text { LCD projectors and e-board on my } \\
\text { teaching learning settings. }\end{array}$ & 2.151 & 1.063 & D.A \\
\hline $\begin{array}{l}\text { I do not have enough skills in using ICT } \\
\text { equipment for my teaching methodology. }\end{array}$ & 2.691 & 1.307 & NA/DA \\
\hline $\begin{array}{l}\text { Excellent teaching is possible without } \\
\text { using ICT equipment. }\end{array}$ & 2.978 & 1.025 & NA/DA \\
\hline $\begin{array}{l}\text { ICT training programs are aligned to } \\
\text { novice teachers. }\end{array}$ & 2.849 & 1.049 & NA/DA \\
\hline $\begin{array}{l}\text { In preparing science lessons } \\
\text { ICT requires more time and effort }\end{array}$ & 2.799 & 1.193 & NA/DA \\
\hline
\end{tabular}

\section{Science Teachers in SUC's Region VI ICT Skills}

Data showed that the science teachers are in within adaptation level with a mean of 2.821 . This means that science teachers were already familiar with the various applications and uses of ICT in their teaching learning process and use it occasionally to support their teaching process. (See Table 2)

However, the skills level of Science teachers on designing and publishing internet pages on science subjects, organizing email group and using chat program were in there entry level or teachers have already been introduced to the basic skills and understand the numerous potential of ICT to contribute 
to their teaching strategies but used it very seldom. (See Table 2)

The results of this findings showed that there moderate ICT skills was due to lack of ICT training of Science Teachers, and it was confirmed by the respondents' responses that the majority of teachers had not attended any ICT training courses or development programs during their years of teaching,

Furthermore the unavailability of ICT equipment such as computer wide network, computer in classroom and science laboratories and LCD projectors in classrooms and science laboratories makes their skills more evidently become moderate.

Table 2. Science Teachers' in SUC's Region VI ICT Skills

\begin{tabular}{|c|c|c|c|}
\hline $\begin{array}{c}\text { Familiarity with computers, (computers and accessories such as LCD projectors, screens, } \\
\text { printers, scanners, modems, digital cameras, etc) }\end{array}$ & 3.209 & 0.821 & V.I \\
\hline $\begin{array}{c}\text { A.D. } \\
\text { Managing operating systems (changing desk top settings, date, time region, the degree of } \\
\text { screen clarity) }\end{array}$ & 2.928 & 0.941 & AD.L \\
\hline Organize and save educational files in folders & 3.259 & 0.828 & AD.L \\
\hline $\begin{array}{c}\text { Prepare summaries, abstracts, and educational material using text based programs (eg } \\
\text { Microsoft Word) }\end{array}$ & 3.237 & 0.873 & AD.L \\
\hline Prepare audio-video presentations for class activities & 2.928 & 0.889 & AD.L \\
\hline Use programs to analyze data and create diagrams, register exam results (eg Microsoft Excel) & 2.907 & 1.042 & AD.L \\
\hline $\begin{array}{c}\text { Setting up and deleting educational programs ( scientific programs and CD information } \\
\text { programs such as encyclopedia) }\end{array}$ & 2.734 & 0.921 & AD.L \\
\hline Use science programs for laboratory activities. & 2.727 & 0.931 & AD.L \\
\hline Use search engines to collect science information for lesson preparation & 2.892 & 1.005 & AD.L \\
\hline Design and publish internet pages on science subjects or for student assignments & 2.374 & 0.919 & E.L \\
\hline Use emails to communicate with teachers, students, and parents & 2.669 & 1.093 & AD.L \\
\hline Organize emails groups for distributing information and instructions & 2.41 & 1.027 & E.L \\
\hline Use chat programs (Messenger, blog) & 2.396 & 1.019 & E.L \\
\hline Mean & $\mathbf{2 . 8 2 1}$ & $\mathbf{0 . 7 2 4}$ & AD.L \\
\hline
\end{tabular}

Table 3. Science Teachers' in SUC's Region VI ICT Utilization

\begin{tabular}{|c|c|c|c|}
\hline & $\mathrm{X}$ & S.D. & V.I \\
\hline ICT equipment such as laptop, LCD projectors and TV is fully integrated in my instructional program. & 3.065 & 0.818 & AA \\
\hline I browse/surf the internet to collect learning materials or resources to be utilized in my lessons. & 3.288 & 0.773 & AA \\
\hline I create my own presentation and digital learning materials for student's consumption. & 2.935 & 0.878 & AA \\
\hline $\begin{array}{l}\text { I post home works and exercises/drills for students on school website or other social networking sites } \\
\text { such as Google and yahoo. }\end{array}$ & 1.914 & 0.952 & SE \\
\hline I use ICT equipment such as online network in giving feedback and assessing students learning. & 1.799 & 0.942 & SE \\
\hline I communicate using internet online with parents, students and colleagues. & 2.065 & 1.058 & SE \\
\hline $\begin{array}{l}\text { I utilize the internet in looking for online professional development opportunities such as scholarship } \\
\text { grants. }\end{array}$ & 2.475 & 1.138 & SE \\
\hline I used computerized evaluation materials for student's examination and computation of grades. & 2.734 & 1.12 & AA \\
\hline I conducted researches using computer. & 2.942 & 1.089 & AA \\
\hline $\begin{array}{l}\text { I prepare my own instructional materials such as hand-outs teaching manual resource units, and etc. } \\
\text { using computer. }\end{array}$ & 3.259 & 0.896 & AA \\
\hline $\begin{array}{l}\text { I post additional information to school website or other social network to reinforce and assist students in } \\
\text { their lessons. }\end{array}$ & 2.000 & 1.029 & SE \\
\hline I access various online researches and best practices as my teaching references. & 2.705 & 1.073 & AA \\
\hline I use digital artifacts from my student's assignments as evidence of achievement. & 2.23 & 1.002 & SE \\
\hline $\begin{array}{l}\text { I use online internet in disseminating important announcements and reminders to students and } \\
\text { colleagues. }\end{array}$ & 2.05 & 1.031 & SE \\
\hline $\begin{array}{l}\text { I monitor, evaluate and report students' achievement with the use of ICT such as computer and online } \\
\text { services. }\end{array}$ & 2.115 & 1.091 & SE \\
\hline I indulge myself on online professional development. & 2.554 & 1.029 & AA \\
\hline I use ICT equipment such as computer aided materials on my science laboratory lessons and activities. & 2.734 & 1.011 & AA \\
\hline I use digital images to discuss science topics and lessons. & 2.791 & 1.032 & AA \\
\hline Grand Mean & 2.536 & 0.715 & $\mathbf{A A}$ \\
\hline
\end{tabular}




\section{Science Teachers' in SUC's Region VI ICT Utilization}

As shown on the previous data, the majority of the science teacher respondents had the uncertain attitudes and on adaptation skills level to use ICT. However, the future for ICT is in its appropriate use in the science curriculum, and to enhance the teaching learning process and the critical thinking of the students.

Data reveals that Science teachers of SUC's in Region VI almost always utilizes and integrates ICT tools and infrastructures in their teaching learning process as shown by the data with a mean of $\mathbf{2 . 5 3 6}$. However, there were Science teachers' who seldom used ICT tools in posting homework in their websites, communicating using internet, using digital artifacts from student's assignments and monitor and evaluate students' achievements using online services.(See Table 3).

Based on the profile of the respondents, one of the reasons why most of the science teachers in Region VI do not use ICT much is due to lack of access and unavailability to equipment in classroom, and lack of teachers' training skills in the use of the equipment.

\section{Barriers that Limits Science Teachers in SUC's Region VI Integrating ICT}

Based on the results of the study, the organizational, technological, and policy were the barriers that somewhat limits Science teachers in SUC's Region VI in utilizing ICT, while their perceived individual barriers slightly limits them in integrating ICT in their teaching and learning process.

The results of the findings showed that the perceived technological barriers of Science teachers was due to lack of ICT infrastructures of the different SUC's in Region VI, as majority of the respondents revealed that SUC's in Region VI provide computer laboratories, however there were insufficient number of computers and LCD projectors provided in every classrooms and in science laboratories for teaching learning process.

As to the perceived policy barriers, the Sciences teachers revealed that there is no government support as to ICT policies in the academe; budget for the procurement of ICT facilities and infrastructure were limited, and no priority and concrete plans for the integration of ICT in every State Universities and Colleges in Region VI.

Majority of SUC's have all a wide plans or strategies on how to implement ICT into teaching and learning process in their respective institutions, however, these are still on the planning stage and far behind for the implementation stage in which teachers respondents implicates that they have no such skills and capabilities on the integration of ICT in their teaching process.

The programs provided by the SUC's in region VI for science teachers' professional development in integration of ICT appears to be inadequate with responses on the programs implemented in their respected institutions.

The professional development needs of science teachers regarding ICT use in the science curriculum focus from administrative support and viable planning program, establishing ICT infrastructures and Teachers training programs.

Furthermore, age factor exhibit a significant difference in ICT skills, utilization and individual barriers of science teachers in SUC's region VI, the length of service also shows a very significant difference as to the ICT skills, utilization attitudes, and individual barriers of the teacher respondents. However as to their gender and highest educational attainment, home location and school location, there is no such factor implicating a non-significance difference on the attitudes, skills, utilization and perceived barriers.

\section{Conclusions}

The dissertation study conclusions were drawn from the findings. The fundamental issue that emerged from this study is that the integration of ICT into science curriculum of Science teachers in State Universities and Colleges (SUC's) in Region VI are impeded by structural and operational factors relating to the different SUC's programs and policies.

The role of the teacher in developing ICT use in different SUC's in Region VI is utterly critical, yet there are many obstacles to be faced, in addition to those already listed that emerged more generally. A primary barrier to teachers' readiness and confidence in using ICT - despite general enthusiasm and belief in benefits for learners - is their lack of training, either initially or in-service. This results in lack of proficiency in using ICT, and knowledge of all of the potential uses and roles of ICT in teaching and learning.

The discussion above highlighted several issues that appeared to influence on teacher utilization and integration of ICT in their profession. The three major Issues and findings of this study reveals that inadequate ICT resources, management of ICT integration, and teacher ICT training and attitudes skills, utilization and barriers were considered as a factor issues.

\section{Recommendations}

The recommendations were drawn from the summary and conclusions of the study. The fundamental issue that emerges from this study is that the integration of ICT into science curriculum of science teachers' in region VI is impeded by structural and operational factors relating to the SUC's programs and policies.

1. A 5-year development plan in every state universities and colleges in region VI should be standardize which ICT integration program in the teaching learning process of science teachers be evident;

2. There should be a revision of curriculums were in ICT integration should be mandatory to be implemented within the system;

3. A training need analysis should be conducted for evaluation purposes of the skills and competencies of the teachers to attend trainings and seminars. 
4. More funds should be allocated to augment the needs to improve the existing and securing more ICT infrastructure, facilities and resources.

5. Full financial support should be provided to augment the implementation and sustainability of such program either local funds or outsource funds from private or government partners.

6. An immediate need to change teachers' attitudes toward adoption of modern educational methodologies, such as cooperative and constructive learning process. For this, teachers need suitable training in ICT; this could be achieved by strong training programs to develop their occupational skills in the use of ICT, to remove psychological barriers, and to facilitate their use of ICT in the classroom.
7. Professional and material incentives should be given to encourage teachers to attend training programs to raise their occupational skills.

8. There should be proper monitoring and evaluation on the effect of the implementations of programs.

9. Subsequent research is recommended to explore in more depth and other contexts trends and constraints on ICT integration in the science curriculum in SUC's, and could include observational studies which were beyond the scope of this study. Finally, the theoretical issues in integrating ICT into the science curriculum and the teachers' enhanced role through professional development provide interesting pathways for further research.

Table 4. Barriers that Limit Respondents' Integration of ICT

\begin{tabular}{|c|c|c|c|}
\hline & $\mathrm{X}$ & S.D. & V.I \\
\hline \multicolumn{4}{|l|}{ Organization culture barriers } \\
\hline Lack of training availability to learn ICT & 2.646 & 1.049 & NA \\
\hline Limitations of technical support from organization. & 2.676 & 0.965 & SO.L \\
\hline Interpersonal barriers to share among co-teachers. & 2.403 & 0.953 & SL.L \\
\hline Lack of awareness on the availability of ICT. & 2.518 & 1.072 & SO.L \\
\hline Unavailable ICT training centers to update ICT knowledge. & 2.647 & 1.089 & SO.L \\
\hline Unwillingness of some colleagues to teach others what they have acquired. & 2.579 & 1.052 & SO.L \\
\hline Mean & 2.57 & 0.814 & SO.L \\
\hline \multicolumn{4}{|l|}{ Individual barriers } \\
\hline Lack of confidence and ability to use ICT. & 2.413 & 1.092 & SL.L \\
\hline Lack of learner's motivation towards the use of ICT. & 2.352 & 1.055 & SL.L \\
\hline Language problems towards the use of ICT. & 2.331 & 0.981 & SL.L \\
\hline Fewer preferences in using ICT. & 2.425 & 0.970 & SL.L \\
\hline There is a lack of skills to use ICT. & 2.403 & 0.976 & SL.L \\
\hline Time management problems in learning to use ICT. & 2.489 & 0.981 & SL.L \\
\hline Hectic schedule to use ICT. & 2.518 & 0.981 & SO.L \\
\hline Lack of awareness on various analytical software (SPSS, STATA etc). & 2.662 & 2.020 & SO.L \\
\hline Poor attitude towards acquiring ICT skills. & 2.381 & 1.038 & SL.L \\
\hline Lack of competence in internet searching skills on the part of many Science professors. & 2.439 & 1.036 & SL.L \\
\hline Lack of knowledge about ways to integrate ICT to enhance curriculum. & 2.374 & 1.016 & SL.L \\
\hline Lack of time in school schedules for projects involving ICT. & 2.489 & 0.995 & SL.L \\
\hline Mean & 2.439 & 0.842 & SL.L \\
\hline \multicolumn{4}{|l|}{ Technological barriers } \\
\hline Poor infrastructure development in Science Education on ICT integration & 2.698 & 1.068 & SO.L \\
\hline The cost of internet and online connection is too high. & 2.705 & 1.106 & SO.L \\
\hline Less-availability of ICT equipment intended in Science Education. & 2.842 & 1.065 & SO.L \\
\hline Low computer literacy level in Science Education community. & 2.712 & 1.016 & SO.L \\
\hline Restricted use of available ICT in Science Education & 2.604 & 1.039 & SO.L \\
\hline Inadequate ICT facilities like computer and electronic board in the university. & 2.705 & 1.099 & SO.L \\
\hline High cost of ICT equipment. & 2.799 & 1.098 & SO.L \\
\hline Mean & 2.724 & 0.917 & SO.L \\
\hline \multicolumn{4}{|l|}{ Policy barriers } \\
\hline Government Mandates related to ICT policies in Academe is not supported. & 2.640 & 1.056 & SO.L \\
\hline No policies in implementation that include special rate for internet and online services for universities. & 2.612 & 1.032 & SO.L \\
\hline Budget for ICT availability in academe sector is limited. & 2.662 & 1.081 & SO.L \\
\hline Priority issues on ICT use on the part of the faculty and the university. & 2.655 & 1.048 & SO.L \\
\hline ICT integration is not a school priority. & 2.597 & 1.088 & SO.L \\
\hline Mean & 2.633 & 0.969 & SO.L \\
\hline
\end{tabular}




\section{PROPOSED FACULTY DEVELOPMENT FRAMEWORK FOR SCIENCE TEACHERS OF STATE UNIVERSITIES AND COLLEGES, REGION VI}

\begin{tabular}{|c|c|c|c|c|c|c|}
\hline Goals/Objectives & Intended Outcomes & Key Implementation Strategies & Responsibility & Time Frame & Budget & Monitoring \\
\hline $\begin{array}{l}\text { LEADERSHIP/ADMINSTRATION } \\
\text { 1. To develop the ICT Strategic Plan to } \\
\text { ensure that is aligned with views of the } \\
\text { school community and is referenced by } \\
\text { the appropriate National, State and } \\
\text { SUC's policies. } \\
\text { 2. To establish clear criteria for evaluating } \\
\text { the effects of integrating ICT within } \\
\text { teaching, learning and administration. } \\
\text { 3. To submit annual reports that document } \\
\text { the progress towards the goals within } \\
\text { the ICT Plan } \\
\text { 4. To create ICT Integration team } \\
\text { 5. Appropriate level of funding to achieve } \\
\text { the goals for the integration of ICT. } \\
\text { 6. To continue current budget planning to } \\
\text { ensure a steady spending pattern that } \\
\text { will achieve the school's goals for ICT } \\
\text { integration }\end{array}$ & $\begin{array}{l}\text { 1. The school has a clearly articulated } \\
\text { shared vision for ICT in teaching, } \\
\text { learning and administration, as a result } \\
\text { of collaboratively consulting with key } \\
\text { stakeholders and makes reference to the } \\
\text { appropriate National, State and SUC's } \\
\text { policies } \\
\text { To develop the ICT Strategic Plan to } \\
\text { ensure that is aligned with views of the } \\
\text { school community and is referenced by } \\
\text { the appropriate National, State and } \\
\text { SUC's policies. } \\
\text { To establish clear criteria for evaluating } \\
\text { the effects of integrating ICT within } \\
\text { teaching, learning and administration. } \\
\text { To submit annual reports that document } \\
\text { the progress towards the goals within the } \\
\text { ICT Plan } \\
\text { E-Learning leadership is distributed } \\
\text { across the school to ensure the } \\
\text { integration of ICT is a focus in planning. } \\
\text { To extend current ICT Integration team } \\
\text { ICT resources are up-to-date and allow } \\
\text { the school to respond to modern trends } \\
\text { and rapidly take advantage of future } \\
\text { improvements in ICT delivery and } \\
\text { infrastructure. } \\
\text { To review the ICT levy to ensure an } \\
\text { appropriate level of funding to achieve } \\
\text { the goals for the integration of ICT. } \\
\text { To continue current budget planning to } \\
\text { ensure a steady spending pattern that will } \\
\text { achieve the school's goals for ICT } \\
\text { integration }\end{array}$ & $\begin{array}{ll}\text { 4. } & \text { Complete ICT Review Tool- } \\
\text { survey of School } \\
\text { Administrators, } \\
\text { Director/chairman of ICT and } \\
\text { all teachers } \\
\text { 5. } \\
\text { Reference to National, State } \\
\text { and SUC's policies } \\
\text { 6. } \\
\text { Discuss criteria with } \\
\text { Curriculum Committee } \\
\text { 7. } \\
\text { Establish reliable methods of } \\
\text { collecting data evaluating the } \\
\text { effects of ICT within } \\
\text { teaching, learning and } \\
\text { administration } \\
\text { Set up SUC's based } \\
\text { collaborative teams for ICT } \\
\text { integration } \\
\text { SUC's coordinator becomes } \\
\text { responsible for strategic } \\
\text { leadership for ICT within their } \\
\text { system } \\
\text { Documentation of ICT } \\
\text { integration strategies used in } \\
\text { each subject area } \\
\text { Maintain budget plans which } \\
\text { 11. } \\
\text { are always forward-planned to } \\
\text { the life of the current } \\
\text { equipment. }\end{array}$ & $\begin{array}{l}\text { - } \quad \begin{array}{l}\text { ICT Directors/ } \\
\text { Chairmen }\end{array} \\
\text { - SUC's Integration Team/ } \\
\text { Committee }\end{array}$ & $\begin{array}{c}\text { June-September } \\
, 2014\end{array}$ & & Annual \\
\hline
\end{tabular}




\section{ICT PROFESSIONAL LEARNING}

1. Prioritization of professional learning with ICT and about ICT:

- $\quad$ To develop to a high priority within total Professional Learning program for Science Teachers

- $\quad$ To establish a formal process for developing and recording ICT skill development for the use of ICT and for the integration of ICT within teaching and learning.

- $\quad$ To ensure that course writing includes specific integration of ICT for science teachers and for student use.

- $\quad$ To provide more time and access for professional learning with ICT and about ICT

- $\quad$ To maintain flexible delivery of ICT professional learning through

face-to-face and online activities provided by in-house or pre-service trainings of colleagues or external experts

- $\quad$ To provide time for more staff to support others in professional learning with ICT and about ICT

2. To develop Professional Learning Plan that:

- $\quad$ Are regularly audited

- $\quad$ Take into account individual, schoo and system needs and targets

- $\quad$ Enable on-going access and flexible use of resources and facilities

3. To develop an online database to enable teachers and administrative staff record achievement of individual, school and system targets for the use of ICT

4. To share innovative practice
There is a high priority of professional learning with ICT and about ICT for science teachers.

1. Professional learning with and about ICT allows teachers to:

- Explore, understand and utilize ICT in teaching, communication, management and administration

- $\quad$ Integrate ICT in ways that produce more effective and more efficient teaching and learning

- $\quad$ Evaluate, create and share online learning resources with colleagues and students locally and globally

- $\quad$ To develop to a high priority within tota Professional Learning program

- To establish a formal process for recording ICT skill development and for the integration of ICT within teaching, learning and administration

- To ensure that course writing includes specific integration of ICT for teachers and for student use

- $\quad$ To provide more time and funding for professional learning with ICT and about ICT

- $\quad$ To maintain flexible delivery of ICT professional learning through

face-to-face and online activities provided by in-house colleagues or external experts

2. Staff members maintain Professional Learning Plans and the impact of ICT professional learning is constantly evaluated on the basis of meeting individual, school and system needs and targets.

- $\quad$ To development of Professional

Learning Plans that Are regularly audited

- Take into account individual, school and system needs and targets

- $\quad$ Enable on-going access and flexible use of resources

\begin{tabular}{|c|c|c|c|}
\hline $\begin{array}{l}\text { Use TNA survey from the } \\
\text { basis for understanding ICT } \\
\text { PD needs of teachers and to } \\
\text { assist in setting goals } \\
\text { Include ICT skill development } \\
\text { report from TNA survey in } \\
\text { Annual Review Meeting with } \\
\text { the Administrators and } \\
\text { Stakeholders } \\
\text { Set specific dates for ICT } \\
\text { in-services and pre-service } \\
\text { training for science teachers. } \\
\text { Develop a database for } \\
\text { recording all professional } \\
\text { learning } \\
\text { Establish a train-the-trainer } \\
\text { model with time given to } \\
\text { trainers to work with others } \\
\text { Employ ICT Coaches to assist } \\
\text { integrate ICT in the classroom } \\
\text { Utilize emergency to cover } \\
\text { teachers doing PD } \\
\text { Increased teacher PD to } \\
\text { implement to ensure } \\
\text { productive results in ICT } \\
\text { integration process. } \\
\text { Development of ICT } \\
\text { Integration Website for use by } \\
\text { teachers } \\
\text { Professional Learning Plan } \\
\text { template developed } \\
\text { Online database developed to } \\
\text { allow entry of information on } \\
\text { all aspects and allow auditing } \\
\text { Subscription of teachers to } \\
\text { online groups } \\
\text { Development of teacher blogs } \\
\text { and forums } \\
\text { Published list used to assist } \\
\text { others to find people to help } \\
\text { with specific ICT advice }\end{array}$ & $\begin{array}{ll}\text { - } & \text { ICT Directors/Chairmen } \\
\text { - } & \text { VP- Administration } \\
\text { - } & \text { VP-Acad. Affairs } \\
\text { - } & \begin{array}{l}\text { Curriculum Planning } \\
\text { Officers }\end{array} \\
\text { - } & \text { Prof. Dev't. Coordinator } \\
\text { - } & \text { SUC's Planning Officers }\end{array}$ & S.Y. 2014-2015 & Annual \\
\hline
\end{tabular}




\begin{tabular}{|c|c|c|c|c|c|}
\hline & $\begin{array}{l}\text { - } \\
\text { To develop an online database to enable } \\
\text { teachers and administrative staff record } \\
\text { achievement of individual, school and } \\
\text { system targets for the use of ICT } \\
\text { 3. } \quad \text { Teachers use ICT tools to plan, access } \\
\text { and share professional learning online } \\
\text { within the school network and globally in } \\
\text { timely, focused and practical ways. To } \\
\text { share innovative practice } \\
\text { Maintenance of KLA based sharing } \\
\text { - } \quad \text { Publishing of innovative practice online } \\
\text { Development of "experts" list to assist } \\
\text { others learning specific practices }\end{array}$ & & & & \\
\hline $\begin{array}{l}\text { ICT INFRASTRUCTURE } \\
\text { 1. } \\
\text { - } \quad \text { Tetwork } \\
\text { To integrate and expand wireless access } \\
\text { to cover all areas of the school to } \\
\text { achieve successful implementation of } \\
\text { ICT integration } \\
\text { - To development and implement a } \\
\text { Content Management System for } 24 / 7 \\
\text { availability of resources } \\
\text { To improve internet connection for } \\
\text { Science Teachers and students to } \\
\text { achieve successful implementation of } \\
\text { Integration. } \\
\text { To improve power supply and secure } \\
\text { charging stations and storage to achieve } \\
\text { successful implementation of } \\
\text { Integration } \\
\text { Hardware Delivery } \\
\text { 2. }\end{array}$ & 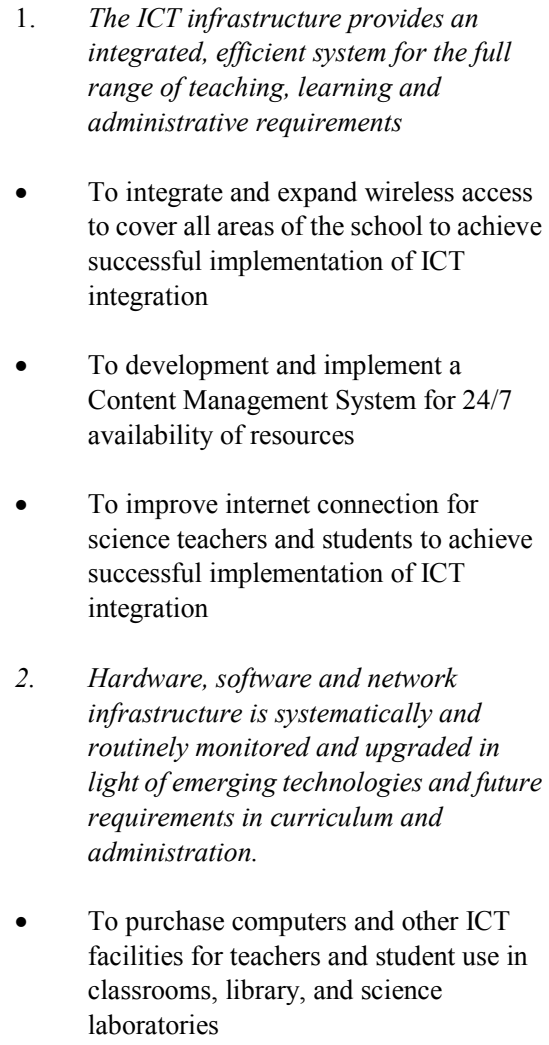 & $\begin{array}{ll}\text { 1. } & \text { Infrastructure Audit } \\
\text { 2. } & \begin{array}{l}\text { Upgrade wireless controller to } \\
802.11 \mathrm{n} \text { and purchase of more } \\
\text { access points }\end{array} \\
\text { 3. } & \begin{array}{l}\text { Install access points as } \\
\text { required throughout school } \\
\text { 4. } \\
\text { Plans developed as part of } \\
\text { library, classroom and } \\
\text { laboratory redevelopment } \\
\text { Submission to College Board }\end{array} \\
\text { 5. } & \begin{array}{l}\text { Purchase a mixture of laptops } \\
\text { on trolleys and computer } \\
\text { desktop systems }\end{array} \\
\text { 6. } & \text { Research Work } \\
\text { 7. } & \begin{array}{l}\text { Annual budget submitted to } \\
\text { Business Manager and the } \\
\text { College Board }\end{array} \\
\text { 8. } & \begin{array}{l}\text { ICT Levy provides some } \\
\text { income from parents }\end{array} \\
\text { 9. Adjustments made as required }\end{array}$ & $\begin{array}{ll}\text { - } & \text { ICT Directors/Chairmen } \\
\text { - } & \text { VP- Administration } \\
\text { - } & \text { VP-Acad. Affairs } \\
\text { - } & \text { Curriculum Planning } \\
\text { - } & \text { Pfficers } \\
\text { - } & \text { SUC's Dev't. Coordinator } \\
& \end{array}$ & S.Y. 2014-2015 & Annual \\
\hline
\end{tabular}


- To complete data projector system installations to all classrooms, and laboratory rooms.

- To install some Interactive White Boards if criteria for use are met

- To develop video conferencing systems

3. Software Delivery

- To continue current arrangements with software delivery

- $\quad$ Technical Support

4. To continue current arrangements with technical support

5. Budgeting of Resources

- To continue current arrangements with budgeting
- To complete data projector system installations to all classrooms and laboratories

- To install some Interactive White Boards if criteria for use are met

- To develop video conferencing systems

3. Technical support is readily available to minimize disruptions to learning, teaching and administration

4. ICT budgeting provides for continual upgrading to allow the school to rapidly take advantage of future improvements in ICT delivery and infrastructure.
in

- $\quad$ To continue current arrangements with budgeting

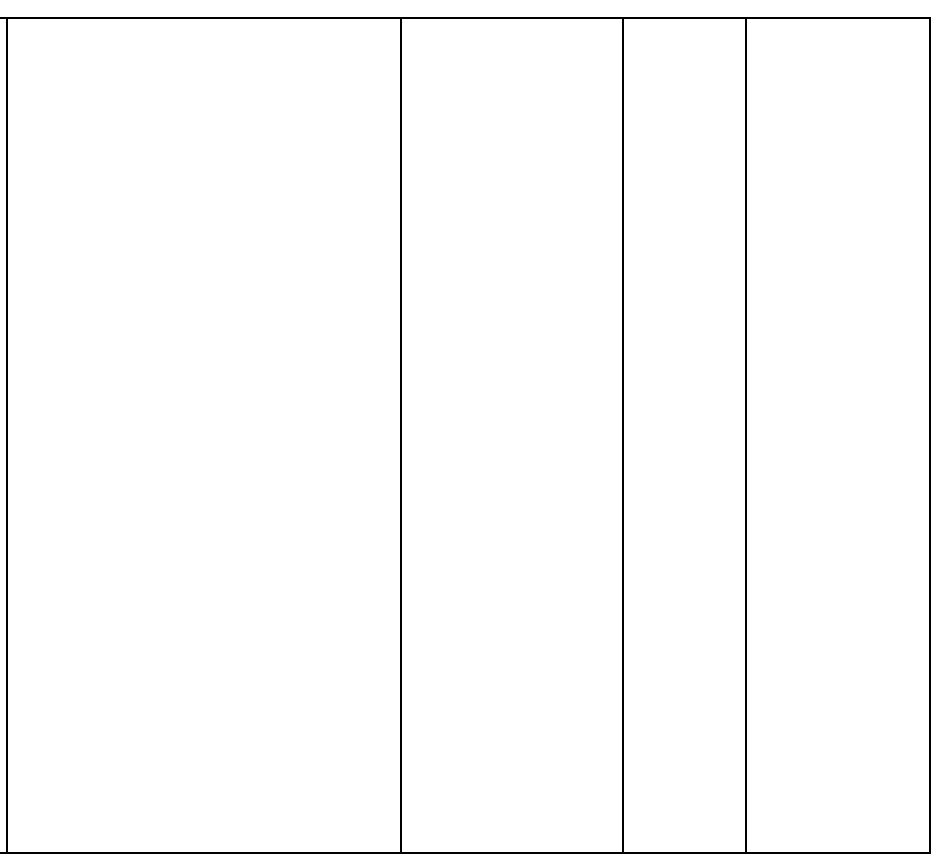




\section{REFERENCES}

[1] Abu Bakar, K. \& Tarmizi, R. A. (1995) Teacher preparation concerns: Professional Needs of Malaysian Secondary School Science Teachers, Paper presented at National Association of Research in Science Teaching Conference, San Franciso, April

[2] Ailing Qiao and Ke-kang He. The Role and Implement of the Teachers' ET Training, Open Education Research. Open Education Research.2005, 11(5): 92-96.

[3] Alan, S. W. (2010). Review article: Effectiveness of web-based learning in the Middle East and North Africa (MENA) region. Proceedings of the Seventh International Conference on eLearning for Knowledge-Based Society, 16-17 December, Bangkok.

[4] Ali, G.A. \& Magalhaes, L. 2008, "Barriers to implementing e-learning: A Kuwaiti case study", International Journal of Training and Development, vol. 12, no. 1, pp. 36-53.

[5] Al-Segghayer, K. (2001). The Effect of Multimedia Annotation Modes on L2 Vocabulary Acquisition: A Comparative Study. Journal of Language Learning \& technology, 5(1): pp.202-232.

[6] Amold Nicholas, E. S. (2010). Blog as a learning space: Creating a Text of Talk. Proceedings of the Seventh International Conference on eLearning for Knowledge-Based Society, 16-17 December, Bangkok.

[7] Asim, A. E., Kalu I. \& Ani B. O.(2003) Assessment of Information and Communication Technologies (ICT) skills development focus of Computer Literacy Centers in Cross River State, Nigeria. Proceedings of the 44th Annual Conference on ICT.

[8] Baldwin-Evans, K. 2004, "Employees and e-learning: What do the end users think?" Industrial and Commercial Training, vol. 36, no. 7, pp. 269-74.

[9] Beasley, W. (1999) Meeting the needs of science teachers and students: The Philippines experiment, in Ware, S. (ed.) in Science and Environment Education: Views from Developing Countries, Secondary education series: World Bank

[10] Becta. (2003). What the Research Says about Using ICT in Maths. UK: Becta ICT Research.

[11] Becta (2003). Primary schools - ICT and Standards. An analysis of national data from Ofsted and QCA by Becta. Coventry: Becta. http://www.becta.org.uk/research/research. cfm?section $=1 \&$ id $=538$

[12] Berce, J., Lanfranco, S. \& Vehovar, V. (2008). E-governance: Information and communication technology, knowledge management and learning organisation culture. Informatica, $32,189-205$.

[13] Burton-Jones, A. \& Hubona, G.S. 2003, The Mediation of External Variables in the Technology Acceptance Model, Working paper, Department of Computer Information Systems, Georgia State University.

[14] Chen, C.-H., \& Howard, B. (2010). Effect of live simulation on middle school students' attitudes and learning toward science. Educational Technology \& Society, 13(1), 133-139.

[15] Chitanana L, Makaza D, Madzima K (2008). The current state of elearning at universities in Zimbabwe: Opportunities and challenges. Int. J. Educ. Dev. Using ICT, 4(2): 1-12.

[16] Cuban, L., (1999, 4 August). The Technology Puzzle. Education Week, 47, 68.

[17] Demetriadis, S., et.al., (2003). Culture In Negotiation: Teachers' Acceptance/Resistance Attitudes Considering The Educational Technology \& Society 4(4)

[18] Demiraslan Y., Usluel Y. K. (2006). Analyzing the Integration of Information and Communication Technologies into Teaching-Learning Process According to Ac-tivity Theory. Eurasian Journal of Educational Research 23:38-49.

[19] Empirica. (2006). Benchmarking access and use of ICT in European schools: Final report from head teacher and classroom teacher surveys in 27 European countries. Retrieved 15 August, 2008 from http://ec.europa.eu/informat ion_society/eeurope/i2010/docs/studies/final_report_3.pdf 